\title{
Effects of increased temperatures on Gammarus fossarum under the influence of copper sulphate
}

\author{
Lara Schmidlin • Stefanie von Fumetti • \\ Peter Nagel
}

Accepted: 18 November 2014/Published online: 26 November 2014

(C) Springer Science+Business Media New York 2014

\begin{abstract}
The specialised fauna of freshwater springs will have to cope with a possible temperature rise owing to Global Change. It is affected additionally by contamination of the water with xenobiotics from human activities in the surrounding landscape. We assessed the combined effects of temperature increase and exposure to toxins in laboratory experiments by using copper sulphate as a model substance and Gammarus fossarum Koch, 1835, as the model organism. This amphipod is a common representative of the European spring fauna and copper ions are widespread contaminants, mainly from agricultural practice. The experiments were conducted in boxes placed in flow channels and the water temperatures were varied. The gammarids were fed with conditioned beech leaf discs. The feeding activity of the amphipods was quantified on the level of the organism; and the respiratory electron transport system (ETS) assay was conducted in order to determine changes on the cellular level in the test organisms. The results show that the feeding activity increased slightly with higher water temperature. The sub-lethal copper dose had no significant effect other than a trend towards lower feeding activity. The ETS activity was significantly higher at the higher water temperatures, and the copper ions significantly lowered the ETS activity of the organisms. The combination of the two methods was useful when testing for combined effects of environmental changes and pollutants on a species. From the results one can reasonably infer a higher risk of adverse effects with increase in water temperature and exposure to a particular heavy metal.
\end{abstract}

L. Schmidlin $(\varangle) \cdot$ S. von Fumetti $\cdot$ P. Nagel

Biogeography Research Group, Department of Environmental

Sciences, University of Basel, St. Johanns-Vorstadt 10,

4056 Basel, Switzerland

e-mail: lara.schmidlin@unibas.ch
Keywords Thermal stress - Amphipod . Copper sulphate $\cdot$ Feeding activity . Electron transport system (ETS)

\section{Introduction}

Springs are special ecotones between the groundwater and the surface water (Webb et al. 1998) and are important habitats for numerous specialised and rare species (Lindegaard et al. 1998) which are necessary for the entire ecotone to function sustainably. Freshwaters such as springs are spatially constrained and can be regarded as early warning systems (Woodward et al. 2009). They can be strongly influenced by pollutants because of their small size, their isolation and because of the direct connection to the groundwater. Spring species are adapted to the relatively stable environmental conditions in springs (e.g. Danks and Williams 1991; Ferrington 1995), many of them being cold-stenothermal (e.g. Fischer et al. 1998). Global Change is causing an increase in temperature, and since a few years extreme events such as heat waves and floods are becoming more frequent in the temperate regions (IPCC 2007). It has been shown that freshwaters and their biodiversity are especially vulnerable towards Global Change (e.g. Heino et al. 2009; Woodward et al. 2010). The water temperature affects macroinvertebrates directly, especially if they are cold-water-adapted species (Heino et al. 2009). It is therefore important to investigate the effects of elevated water temperatures on macroinvertebrates, using realistic temperature scenarios which could occur in nature. This is becoming more important because extremely warm and dry summers are occurring more frequently (Vittoz et al. 2013), so the organisms need to adapt to fast elevating temperatures. Furthermore water temperature raises the 
toxicity of substances such as fungicides for non-target organisms (Bat et al. 2000; Holmstrup et al. 2010), making the organisms more susceptible to environmental warming. These interactions are of interest in ecotoxicology, since temperature has a large impact on species, especially in combination with toxicants. It is therefore important to conduct tests combining both stressors.

Copper salts are important ingredients in many fungicides and fertilisers used in agriculture (e.g. de OliveiraFilho et al. 2004) and are one of the most widespread contaminants (Debelius et al. 2009). They also act as an algaecides and hence are used for control of phytoplankton and aquatic weeds (e.g. Effler et al. 1980). Copper salts have been introduced into water bodies as aquatic molluscicides (e.g. Guida et al. 2008). Although a certain amount of copper ions are essential for most organisms, they pose a threat to many aquatic organisms in general when available in excess in water (Martins et al. 2011). They are strong fish poisons as well as one of the most toxic metals for microalgae, being toxic at concentrations as low as $1 \mu \mathrm{g} / \mathrm{L}$ (Debelius et al. 2009). Terrestrially applied pesticides can be flushed into springs and rivers through means of runoff. This will take place more regularly when heavy rainfalls occur more frequently. In vineyards where fungicides containing copper ions are commonly applied (e.g. Ruyters et al. 2013), pollution of nearby springs is likely. Although copper salts in soils are strongly immobilized, there has also been evidence of them migrating through soil profiles in vineyards (Komarek et al. 2010). Groundwater quality is then under risk and hence spring water quality is also affected. It is, however, more likely that springs are contaminated via runoff of freshly applied fungicides, intensified by heavy rainfall.

Amphipods mainly take up ions such as $\mathrm{Cu}^{2+}$ via their gills since these are a large adsorptive organ system (Reichmuth et al. 2010). This makes them especially susceptible to water-borne pollutants (Rinderhagen et al. 2000). Previous studies have been conducted on the effects of copper salts for example on G. pulex (e.g. Taylor et al. 1998; Güven et al. 1999; Brooks and Mills 2003). In a study testing the effects of copper ions on the feeding rate and digestive enzymes of $G$. fossarum it was found that organisms exposed to a metallic contaminated site had inhibited digestive enzymes and a decreased feeding activity (Dedourge-Geffard et al. 2009). The impact of $\mathrm{Cu}^{2+}$ is expected to be stronger at higher temperatures because the higher temperatures can cause increased breathing as a consequence of the elevated metabolic activity and hence increased absorption of ions (Lemus and Chung 1999). Copper ions are important components in the haemocyanin, and are highly regulated in all gammarid species (Taylor and Anstiss 1999). Crustaceans including the gammarid species have detoxification mechanisms to counteract toxicity by metal ions (Geffard et al. 2010). However, if these detoxification mechanisms are unable to regulate the excess of internalized metal, the excess leads to physiological disturbances (Lebrun et al. 2012). Amphipods are frequently used as bioindicators in aquatic toxicity tests owing to their prolific breeding, high abundance in nature and sensitivity to anthropogenic compounds such as metal ions in water bodies which they inhabit (e.g. Ladewig et al. 2006). Gammarus fossarum Koch, 1835 (Crustacea; Amphipoda) is a typical inhabitant of running waters rich in oxygen (Lukancic et al. 2009) and abundantly inhabits springs and spring brooks in mountainous regions of Central Europe (Janetzky 1994; Pöckl et al. 2003). This species is more sensitive than Gammarus pulex $(\mathrm{L})$ towards contamination of water, low oxygen and low pH (Rinderhagen et al. 2000; Alonso et al. 2010), but is a relatively robust representative of the macrozoobenthos of springs. G. fossarum is mainly an efficient shredder, but also feeds on fine particulate organic matter (FPOM) (Moog 1995). It plays a fundamental role in organic matter breakdown in springs and spring brooks and hence in the distribution of coarse particulate organic matter (CPOM) and FPOM (Wagner 1990; Simcic and Brancelj 2006). Furthermore it is fairly easy to keep in the laboratory. The use of a crenobiontic species for our experiments would have been more desirable; however these taxa do not occur abundantly and are therefore not suitable for experiments which require large numbers of individuals. For these reasons $G$. fossarum can be deemed a suitable organism for assessing possible impacts of Global Change and pollution.

We decided to make use of the following two endpoints in our experiments: The feeding activity and the respiratory electron transport system (ETS) activity. It is known that the metabolic activity of an organism can be expressed for example by the feeding activity and the respiratory rate. These parameters were chosen because one of them reveals information on the metabolism of the organism on the level of the organism and the other one reflects the metabolic activity of the organism on the cellular level. Furthermore the feeding and ETS activity are replicable in a fairly short time frame.

The feeding activity gives insight into the metabolic activity of the organisms on the level of the organism. Such a non-lethal endpoint is suitable for assessing low concentrations of pollutants which are found in nature (Pestana et al. 2007). The feeding activity is also a good indicator for environmental stressors (Pestana et al. 2007) such as pollution and temperature increases.

The ETS assay is a useful tool for assessing the metabolic activity of an organism on the cellular level. The ETS is an enzyme system found in the inner mitochondrial membranes of eucaryotes which controls the oxygen consumption (Toth 1999). The results obtained from this assay 
reflect the maximum oxygen consumption when all enzymes are functioning optimally (Kenner and Ahmed 1975).

The objective of this study was to find out how G. fossarum reacts to stepwise increasing water temperatures and the additional stressor copper on a sub-lethal level. This was tested in a laboratory under controlled conditions using an environmentally realistic copper ion concentration. Rising water temperatures are postulated to enhance the effects of copper pollution and generally increase the metabolic activity of $G$. fossarum. We assumed that both the feeding and ETS activity of $G$. fossarum would increase with rising temperatures, but decrease under the influence of copper ions.

\section{Materials and methods}

\section{Chemicals}

Copper sulphate penta-hydrate $\left(\mathrm{CuSO}_{4} \cdot 5 \mathrm{H}_{2} \mathrm{O}\right.$, Merck, Lot no. A921690 717), magnesium sulphate hepta-hydrate $\left(\mathrm{MgSO}_{4}\right.$. $7 \mathrm{H}_{2} \mathrm{O}$, Merck, Lot no. A966886 729), formaldehyde solution $\min 37 \%$ GR (HCHO, Merck, Lot no. K23876703 714), ortho-phosphoric acid $85 \% \quad\left(\mathrm{H}_{3} \mathrm{PO}_{4}\right.$, Merck, Lot no. $\mathrm{K} 43024773$ 150) and potassium dihydrogen phosphate $\left(\mathrm{H}_{2} \mathrm{KPO}_{4}\right.$, Merck, Lot no. K23916773 715) were purchased from Merck (Germany). Polyvinyl pyrrolidone (PVP) $\left[\left(\mathrm{C}_{6} \mathrm{H}_{9} \mathrm{NO}\right)_{\mathrm{x}}\right.$, Sigma Aldrich, Lot no. BCBG5331V], TritonX-100 (Triton, Sigma Aldrich, Lot no. BCBC9283V), $\beta$-Nicotinamide adenine dinucleotide, reduced disodium salt hydrate (NADH, Sigma Aldrich, Lot no. 071M7021V), $\beta$-Nicotinamide adenine dinucleotide phosphate sodium salt hydrate (NADPH, Sigma Aldrich, Lot no. SLBH3107V), 2-piodo-phenyl 3-p-nitrophenyl 5-phenyl tetrazolium chloride (INT, Sigma Aldrich, Lot no. BCBG6164V) and sodium phosphate dibasic dodeca-hydrate $\left(\mathrm{HNa}_{2} \mathrm{O}_{4} \mathrm{P} \cdot 12 \mathrm{H}_{2} \mathrm{O}\right.$, Sigma Aldrich, Lot no. SZBB201AV), were obtained from Sigma Aldrich (Germany).

\section{Collection of test organisms}

G. fossarum specimens were collected from one natural spring, a rheocrene, in the Röserental near Liestal, in Switzerland (for further information see von Fumetti and Nagel (2012)), and transported in spring water with leaves from the spring to the laboratory. Individuals of both sexes were collected and their size ranged from about 8 to $14 \mathrm{~mm}$ body length, the majority of the gammarids being about $10 \mathrm{~mm}$ long. The wet weight of the gammarids used in these experiments ranged from 8 to $14 \mathrm{mg}$ and the selected specimens showed no form of parasitism and their movement was not impaired. They were kept at $10{ }^{\circ} \mathrm{C}$ in the transport containers for $84 \mathrm{~h}$ for acclimatisation to laboratory conditions before being used in an experiment.

Conditioning of the leaf discs

As the spring the gammarids were obtained from is surrounded mainly by beech trees, these leaves form the most important food source for many of the spring inhabitants including $G$. fossarum. Therefore we collected beech leaves (Fagus sylvatica L.) from the litter layer near the spring after abscission in autumn. The collected leaves were dried in an oven at $40^{\circ} \mathrm{C}$ and then stored as described by Bloor (2010). Leaf discs $(\varnothing 1 \mathrm{~cm})$ were cut out of these dried leaves with the help of a cork borer and then weighed. Twelve leaf discs (more info see below) were always weighed together and then placed together in numbered stainless steel herb infusers $(\varnothing 9 \mathrm{~cm})$. The infusers were submerged into aerated spring water with FPOM from the spring for conditioning at a water temperature of $\pm 17^{\circ} \mathrm{C}$ for four weeks.

\section{Measured physical and chemical parameters}

The oxygen saturation $(\%)$ and concentration $(\mathrm{mg} / \mathrm{L})$ as well as the $\mathrm{pH}$ and conductivity $(\mu \mathrm{S} / \mathrm{cm})$ of the spring water were measured in the field using portable meters (Wissenschaftlich-Technische Werkstätten, Weilheim, Germany). The phosphate $\left(\mathrm{PO}_{4}{ }^{3-}\right)$, nitrate $\left(\mathrm{NO}_{3}{ }^{-}\right)$, nitrite $\left(\mathrm{NO}_{2}{ }^{-}\right)$and ammonia $\left(\mathrm{NH}_{4}^{+}\right)$concentrations (all in $\mathrm{mg} / \mathrm{L}$ ), of the spring water were measured with ICP-OES (SPECTRO MS, Spectro Analytical Instruments GmBh, Kleve, Germany).

\section{Choice of copper ion concentration}

In order to decide what sub-lethal concentration of copper ions to use for our experiments, we conducted $\mathrm{LC}_{50}$-tests with copper sulphate and G. fossarum at 10,14 and $18{ }^{\circ} \mathrm{C}$ for $96 \mathrm{~h}$. During this time the gammarids were not fed. The copper ion concentrations for the $\mathrm{LC}_{50}$ testing were chosen based on values from a previous study (Güven et al. 1999). Three temperatures were tested, using 126 gammarids per temperature with 18 per tested concentration. Two controls and five nominal concentrations namely $0.05,0.08,0.15$, 0.3 and $0.5 \mathrm{mg} \mathrm{Cu}^{2+} / \mathrm{L}$ were tested. The actual test concentrations of the copper ions in the water were not tested owing to technical and financial restrictions. The $\mathrm{LC}_{50^{-}}$ values of these tests exhibited a clear pattern in that with higher temperatures less $\mathrm{Cu}^{2+}$ was tolerated by the gammarids; the $\mathrm{LC}_{50}$-value at $10^{\circ} \mathrm{C}$ after $96 \mathrm{~h}$ was $0.239 \mathrm{mg} \mathrm{Cu}^{2+} / \mathrm{L}$, at $14{ }^{\circ} \mathrm{C}$ was $0.188 \mathrm{mg} \mathrm{Cu}^{2+} / \mathrm{L}$ and at $18{ }^{\circ} \mathrm{C}$ was $0.135 \mathrm{mg} \mathrm{Cu}^{2+} / \mathrm{L}$. The $\mathrm{LC}_{10}$-value at $10^{\circ} \mathrm{C}$ after $96 \mathrm{~h}$ was $0.164 \mathrm{mg} \mathrm{Cu}^{2+} / \mathrm{L}$, at $14{ }^{\circ} \mathrm{C}$ was 
Table $1 \mathrm{LC}_{50}$-values and confidence limits

\begin{tabular}{lllllll}
\hline $\begin{array}{l}\text { Temperature } \\
{\left[{ }^{\circ} \mathrm{C}\right], \text { time }} \\
{[\text { hours }]}\end{array}$ & \begin{tabular}{l}
$\mathrm{LC}_{50^{- \text {value }}}\left[\mathrm{mg} \mathrm{Cu}^{2+} / \mathrm{L}\right]$ \\
\hline 10,96
\end{tabular} & $\begin{array}{l}95 \% \text { lower } \\
\text { confidence limit } \\
{\left[\mathrm{mg} \mathrm{Cu}^{2+} / \mathrm{L}\right]}\end{array}$ & $\begin{array}{l}95 \% \text { upper } \\
\text { confidence limit } \\
{\left[\mathrm{mg} \mathrm{Cu}{ }^{2+} / \mathrm{L}\right]}\end{array}$ & $\begin{array}{l}\mathrm{LC}_{10} \text {-value } \\
{\left[\mathrm{mg} \mathrm{Cu}^{2+} / \mathrm{L}\right]}\end{array}$ & $\begin{array}{l}95 \% \text { lower } \\
\text { confidence limit } \\
{\left[\mathrm{mg} \mathrm{Cu}^{2+} / \mathrm{L}\right]}\end{array}$ & $\begin{array}{l}95 \% \text { upper } \\
\text { confidence limit } \\
{\left[\mathrm{mg} \mathrm{Cu}^{2+} / \mathrm{L}\right]}\end{array}$ \\
14,96 & 0.239 & 0.095 & 0.294 & 0.164 & 0.016 & 0.223 \\
18,96 & 0.188 & 0.141 & 0.238 & 0.1 & 0.045 & 0.122 \\
10,264 & 0.135 & 0.111 & 0.166 & 0.073 & 0.05 & 0.091 \\
\hline
\end{tabular}

$0.100 \mathrm{mg} \mathrm{Cu}^{2+} / \mathrm{L}$ and at $18^{\circ} \mathrm{C}$ was $0.073 \mathrm{mg} \mathrm{Cu}^{2+} / \mathrm{L}$. Since the main experiments were designed to last 12 days (264 h) we decided to run a small test with 10 gammarids at $10{ }^{\circ} \mathrm{C}$ for 12 days. These gammarids were fed ad libitum with $F$. sylvatica leaf discs because 12 days of starving would have stressed and weakened the gammarids additionally. The $\mathrm{LC}_{50}$-value at $10^{\circ} \mathrm{C}$ after $264 \mathrm{~h}$ was $0.304 \mathrm{mg} \mathrm{Cu}^{2+} / \mathrm{L}$ and the $\mathrm{LC}_{10}$-value was $0.167 \mathrm{mg} \mathrm{Cu}^{2+}$ / $\mathrm{L}$ (Table 1). The latter value is nearly identical to the one obtained at $10^{\circ} \mathrm{C}$ after $96 \mathrm{~h}\left(0.164 \mathrm{mg} \mathrm{Cu}^{2+} / \mathrm{L}\right)$. The $\mathrm{LC}_{10}$-value of $0.164 \mathrm{mg} \mathrm{Cu}^{2+} / \mathrm{L}$ received after $96 \mathrm{~h}$ at $10{ }^{\circ} \mathrm{C}$ was thus chosen as the sub-lethal concentration for further feeding and ETS tests. By comparison copper salt concentrations in natural unimpacted waters are mainly influenced by the geology of the water shed of the area and are in the range of $<4.00 \mu \mathrm{g} / \mathrm{L}$ (Schönborn and Risse-Buhl 2013). In streams natural copper ion concentrations are $4-12 \mu \mathrm{g} / \mathrm{L}$ and in groundwater it is less than $0.1 \mu \mathrm{g} / \mathrm{L}$ (Standard methods for the examination of water and wastewater 1998). The copper salt concentration of impacted waters can be considerably higher, and in a stream in Northern Germany for example copper ion concentrations of up to $13 \mathrm{mg} / \mathrm{L}$ have been measured (Sridhar et al. 2001).

\section{Experimental design}

The experiments were conducted in a laboratory in four stainless steel flow channels. Each unit consisted of the actual flow channel $\left(1 \times 0.4 \times 0.2 \mathrm{~m}^{3}\right)$, a tube through which water flowed into a rain barrel (60 litres) functioning as a water reservoir, an aquarium pump (EHEIM, compact 1000, Deizisau, Germany) to pump the water into the channel and a cooling unit (Aqua Medic Titan 500, Blessendorf, Germany). The water temperature was regulated with this cooling unit with an accuracy of $\pm 0.5^{\circ} \mathrm{C}$. Eight plastic boxes $\left(78 \times 108 \times 67 \mathrm{~mm}^{3}\right)$ were placed in every channel: four plastic boxes were filled with pure spring water (=control groups); the other four were filled with the chosen copper sulphate pentahydrate spring water solution of $0.164 \mathrm{mg} \mathrm{Cu}^{2+} / \mathrm{L}$ (=experimental groups). Spring water from the spring from which the organisms were collected was used so that the presence of a natural microflora was given (Jonsson and Malmquist 2000). The copper ion concentration of the natural spring water was measured with ICP-EOS and found to be $0.00 \mathrm{mg} \mathrm{Cu}^{2+} / \mathrm{L}$. The actual test concentration of copper ions in the water of every box in the experiments was not tested owing to technical and financial restrictions. Six test organisms were placed into each box; this correlates approximately with the natural population density (Jonsson and Malmquist 2000). Organisms were used regardless of their sex, as has been done in other studies (e.g. Cold and Forbes 2004; Alonso et al. 2010; Bundschuh et al. 2009). Twelve leaf discs were placed into every box of six gammarids as the food source. Each box was aerated by a pump (Tetra, APS 50, Melle, Germany) and an air outlet stone (Trixie, Nr. 85501, Tarp, Germany), which was renewed for every experiment. This ensured constant oxygen content of the water over the entire duration of the experiments. The photoperiod was $11 \mathrm{~h}$ light, $13 \mathrm{~h}$ dark. All flow channels were illuminated by two different aquaria-lights (Juwel Aquarium warm-lite and Juwel Aquarium day-lite). The experiments all lasted 12 days. During this time the temperature was varied. Channel 1 was kept at $10{ }^{\circ} \mathrm{C}$ and functioned as the control channel regarding the water temperature. The water temperatures in the experimental channels were increased as follows: on the first day the water temperature was set at $10{ }^{\circ} \mathrm{C}$, on the fifth day it was raised and on the ninth day it was raised further. The temperature regime of channel 2 was $10,12,14{ }^{\circ} \mathrm{C}$, that of channel 3 was $10,14,16^{\circ} \mathrm{C}$ and that of channel 4 was $10,16,18^{\circ} \mathrm{C}$ (Table 2). The experiments were repeated a total of 5 times to obtain 5 replicates.

Feeding activity

Each flow channel held 4 boxes for feeding tests, 2 were copper-free, and 2 were with copper. The organisms were monitored daily for deaths and dead ones were removed from the boxes. At the end of the experiments all gammarids were preserved in $100 \%$ ethanol, dried at $40{ }^{\circ} \mathrm{C}$ and weighed. The leaf discs they had fed on were also dried at $40{ }^{\circ} \mathrm{C}$ and then weighed. Maltby et al. (2002) and many 
Table 2 Temperature regimes applied in the conducted experiments 1-5. Channel 1: control channel, kept at $10{ }^{\circ} \mathrm{C}$ during the entire experiment. Date start of the experiments. Deaths during the

\begin{tabular}{lllllll}
\hline $\begin{array}{l}\text { Temperature regime } \\
\text { channels 1-4 days 4-8-12 }\end{array}$ & $\begin{array}{l}\text { Exp 1: 5/11/ } \\
2012 \text { deaths }\end{array}$ & $\begin{array}{l}\text { Exp 2: 10/ } \\
\text { 12/2012 deaths }\end{array}$ & $\begin{array}{l}\text { Exp 3: 7/1/ } \\
\text { 2013 deaths }\end{array}$ & $\begin{array}{l}\text { Exp 4: 28/1/ } \\
\text { 2013 deaths }\end{array}$ & $\begin{array}{l}\text { Exp 5: 25/2/ } \\
\text { 2013 deaths }\end{array}$ & $\begin{array}{l}\text { Total deaths per channel } \\
\text { over all experiments }\end{array}$ \\
\hline $10-10-10^{\circ} \mathrm{C}$ & 1 & 1 & & 3 & 2 \\
$10-12-14^{\circ} \mathrm{C}$ & 1 & & & 3 & 4 \\
$10-14-16^{\circ} \mathrm{C}$ & 1 & 1 & 1 & 3 & 7 & 7 \\
$10-16-18{ }^{\circ} \mathrm{C}$ & & 2 & 2 & 3 &
\end{tabular}

experiments are given in total numbers of the 48 per channel; all deaths occurred in the copper-exposed groups and with rising water temperature more deaths occurred other authors using feeding activity as an endpoint for their experiments speak of feeding rates. However, considering that gammarids are shredders and hence do not necessarily eat all the leaf material they process we prefer to use the term feeding activity. We decided to determine an overall feeding activity at the end of each experiment, since it was of interest to us how the temperature elevations affected the feeding activity over the entire duration of the experiment. The feeding activity was determined for every box, according to Maltby et al. (2002), for the 6 organisms together, as described below:

$\mathrm{FA}=((\mathrm{Li} \times$ Control factor $)-\mathrm{Lf}) /($ weight $\times$ time $)$

where FA is the feeding activity, $\mathrm{Li}$ is the initial weight $(\mathrm{mg})$ of the leaves, Control factor was determined experimentally by us and is the loss of weight of leaves during 12 days when no feeding takes place, $\mathrm{Lf}$ is the final weight (mg) of the leaves, weight is the dry weight of gammarids $(\mathrm{mg})$ and time is the duration of experiment (days).

\section{ETS activity}

Each flow channel held 4 boxes for ETS tests, 2 were copperfree, and two were with copper. The ETS activity of the test organisms was determined according to the method originally developed by Packard (1971) and improved by Toth (1999). All experiments started off at $10{ }^{\circ} \mathrm{C}$; the experimental groups were then exposed to higher temperatures, while the controls were kept at $10{ }^{\circ} \mathrm{C}$. The ETS activity was always measured $48 \mathrm{~h}$ after a steady water temperature had been reached in order to detect the influence of the changing water temperatures on the organisms at a cellular level. ETS assays were carried out on days 4,8 and 12 of the experiments. Four test organisms out of one box with copper and four from one without copper, per flow channel, were used. In total 8 test organisms per temperature and a total of 32 gammarids per day were analysed.

To conduct the ETS assay eight live gammarids were removed from the flow channels one by one using tweezers, placed on a tissue and gently patted dry. They were then weighed singly on a microbalance (XP6, METTLER
TOLEDO, Greifensee, Switzerland), placed on a numbered aluminium sheet with some distilled water and then homogenised singly in the homogenisation tube without the distilled water, using $4 \mathrm{~mL}$ of ice-cold homogenising buffer solution [0.1 M sodium phosphate buffer $\mathrm{pH} 8.4,75 \mu \mathrm{M} \mathrm{MgSO}$, $0.15 \%(\mathrm{w} / \mathrm{v})$ polyvinyl pyrrolidne, $0.2 \%(\mathrm{v} / \mathrm{v})$ Triton-X100]. The homogenate was poured into a centrifuge tube and sonicated with an ultrasonic homogeniser (Bandelin Sonopuls HD2070, Berlin, Germany) for $20 \mathrm{~s}$ and stored in an ice solution. The homogenate was then centrifuged (Sigma 2-16 PK, Osterode am Harz, Germany) at $0{ }^{\circ} \mathrm{C}$ for $4 \mathrm{~min}$ at 10000 r.p.m., according to Simcic and Brancelj (2004). The supernatant (in triplicate) was incubated with $1.5 \mathrm{~mL}$ substrate solution [0.1 M sodium phosphate buffer $\mathrm{pH} 8.4,1.7 \mathrm{mM}$ NADH, $0.25 \mathrm{mM}$ NADPH, $0.2 \%$ (v/v) Triton-X-100] and $0.5 \mathrm{~mL}$ reagent solution [2.5 mM 2-p-iodo-phenyl-3-pnitrophenyl-5-phenyl tetrazolium chloride] for $40 \mathrm{~min}$ at $10{ }^{\circ} \mathrm{C}$. Stopping solution [formaldehyde (conc.) $: \mathrm{H}_{3} \mathrm{PO}_{4}$ (conc.) $=1: 1], 0.5 \mathrm{~mL}$, was added immediately after incubation and the formazan production determined spectrophotometrically with the spectroquant ${ }^{\circledR}$ Pharo 300 (Merck, Darmstadt, Germany) by measuring the absorbance of the sample at $490 \mathrm{~nm}$ against the blank.

In order to obtain a conversion to equivalent oxygen the ETS activity was calculated according to Kenner and Ahmed (1975) as follows:

$$
\begin{aligned}
& \text { ETS activity }\left(\mu \mathrm{L} \mathrm{O}_{2} / \mathrm{mg} \times \mathrm{h}\right) \\
& =\left(\left(\mathrm{Abs}^{490 \mathrm{~nm}} \times \mathrm{Vr} \times \mathrm{Vh} \times 60\right) /\right. \\
& (\mathrm{Va} \times \mathrm{Gw} \times \mathrm{t} \times 1.42)
\end{aligned}
$$

where $\mathrm{Abs}^{490 \mathrm{~nm}}$ is the absorption of the sample, $\mathrm{Vr}$ is the final volume of the reaction mixture $(3 \mathrm{~mL}), \mathrm{Vh}$ is the volume of the original homogenate $(4 \mathrm{~mL}), \mathrm{Va}$ is the volume of the aliquot of the homogenate $(0.5 \mathrm{~mL}), \mathrm{Gw}$ is the gammarid wet weight $(\mathrm{mg}), \mathrm{t}$ is the incubation time (min) and 1.42 is the factor for conversion to volume oxygen.

Data analysis

The programme "EPA Probit Analysis Program, Version 1.5” (http://www.epa.gov/) was used to determine 
$\mathrm{LC}_{50^{-}}$and $\mathrm{LC}_{10^{-}}$values of $G$. fossarum specimens for copper sulphate. The programme is based on the method of probit analysis, which is a type of regression used to analyse binomial response variables, in this case concentration and mortality of the test individuals, always at the different temperatures. The method transforms the sigmoid doseresponse curve to a straight line (Newmann 2010). This line may be fitted by the method of weighted least squares (Litchfield and Wilcoxon 1948).

The effects of the copper ion concentration and water temperatures on G. fossarum were tested using one and two way ANOVAs followed by Scheffes's post hoc tests. Prior to the ANOVA analyses assumptions of variance homocedasticity and data normality were tested using Levene's and Kolgomorof-Smirnov's tests. To correct for multiple single comparisons a Bonferroni-Holm correction was applied. The $\alpha$-level was set at 0.05 . Analyses were performed using the Statistical Package for Social Sciences (SPSS) version 21 for Windows (SPSS Inc, Chicago, IL, USA)

\section{Results}

Measured physical and chemical parameters

The temperature of the spring water ranged from 10 to $11{ }^{\circ} \mathrm{C}$; the $\mathrm{pH}$ ranged from 6.9 to 7.4 ; the electrical conductivity of the spring water ranged from 534 to $684 \mu \mathrm{S} /$ $\mathrm{cm}$; the oxygen concentration was between 6.8 and $11.8 \mathrm{mg} / \mathrm{L}$ and the saturation between 65 and $98 \%$; the phosphate $\left(\mathrm{PO}_{4}{ }^{3-}\right)$ and the nitrite $\left(\mathrm{NO}_{2}{ }^{-}\right)$concentrations were $<0.05 \mathrm{mg} / \mathrm{L}$; the ammonia $\left(\mathrm{NH}_{4}{ }^{+}\right)$concentration of the spring water was $<0.1 \mathrm{mg} / \mathrm{L}$ and the nitrate $\left(\mathrm{NO}_{3}{ }^{-}\right)$ concentration was $18.0 \mathrm{mg} / \mathrm{L}$.
Feeding activity

The feeding activity ranged from 0.008 to $0.373 \mathrm{mg} / \mathrm{mg} \times \mathrm{d}$. The lowest value was measured in a copper-exposed box in the control channel at $10{ }^{\circ} \mathrm{C}$ and the highest in a copper-free box in an experimental group with the temperature regime 10-12$14{ }^{\circ} \mathrm{C}$. A tendency towards higher feeding activity at the intermediate temperature regime $10-12-14{ }^{\circ} \mathrm{C}$ in the control group can be noted (Fig. 1).

A two-way ANOVA showed that the copper ions did not have a significant effect on the feeding activity, F (1, $72)=1.5, p=0.225$ and that temperature had a nearly significant effect, $\mathrm{F}(3,72)=2.612, \mathrm{p}=0.058$. The interaction of temperature and copper ions was not significant, $\mathrm{F}(3,72)=0.807, \mathrm{p}=0.494$.

\section{ETS activity}

The ETS values ranged from 0.174 to $1.431 \mu \mathrm{L} \mathrm{O} \mathrm{O}_{2} /$ $\mathrm{mg} \times \mathrm{h}$. The lowest value was measured in a gammarid at $10{ }^{\circ} \mathrm{C}$ exposed to copper ions and the highest in a gammarid at $10^{\circ} \mathrm{C}$ not exposed to copper ions. The ETS values of the gammarids not exposed to copper ions were all higher than the ETS activities of the gammarids exposed to copper ions (Fig. 2).

A two-way ANOVA showed that the copper ions had a highly significant effect on the ETS activities of the gammarids $\mathrm{F}(1,463)=19.625, \mathrm{p}<0.001$. The temperature also had a significant influence on the ETS activities $\mathrm{F}(4,463)=3.683$, $\mathrm{p}=0.006$. The interaction of temperature and copper ions was not significant $\mathrm{F}(4,463)=0.527, \mathrm{p}=0.716$.

A one-way ANOVA comparing the different treatments (copper-free and copper-exposed) in the control channel, channels 2,3 and 4 showed significant $(p=0.002$; $\mathrm{p}<0.001 ; \mathrm{p}=0.030 ; \mathrm{p}=0.028$, respectively) effects of
Fig. 1 Calculated mean feeding activity of $G$. fossarum at the different conditions, with and without copper ion influence. The control channel (1) is always at $10{ }^{\circ} \mathrm{C}$, the experimental channels $(2,3$ and 4) have temperature regimes which range from $10^{\circ}$ to maximum $18{ }^{\circ} \mathrm{C}$. Standard errors are represented by the error bars attached to each column. Pale grey no copper, dark grey copper influence

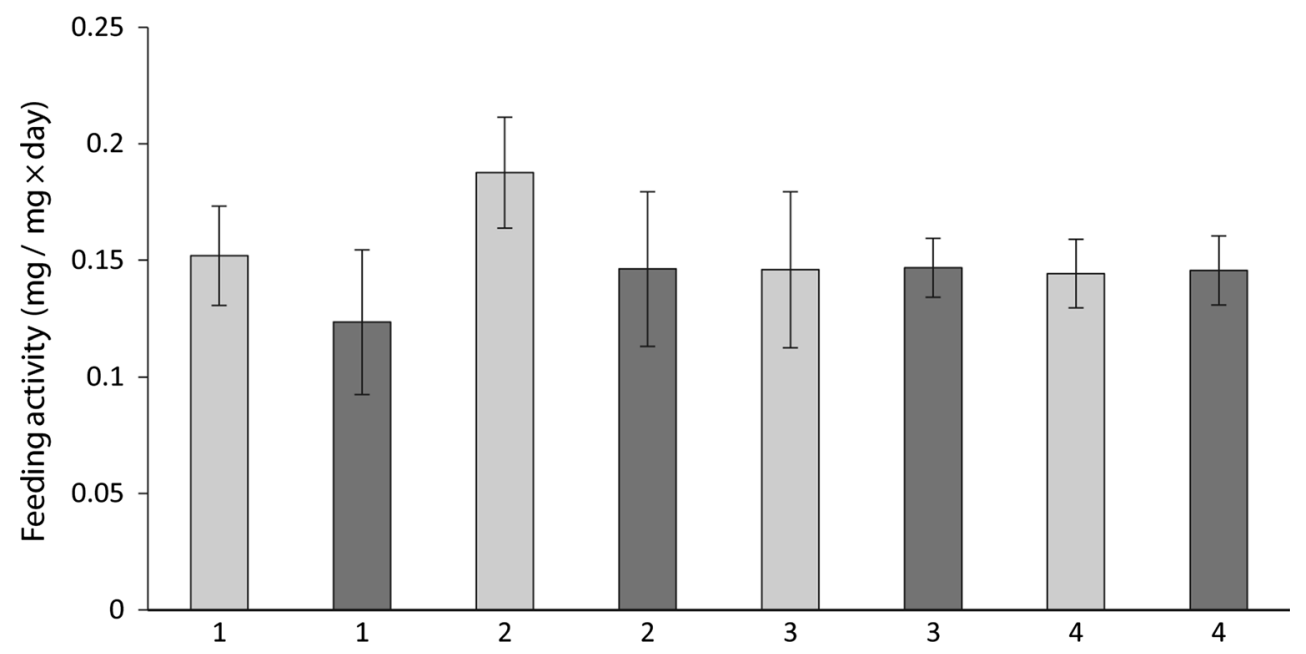


Fig. 2 Mean ETS activities of G. fossarum for all channels with their different temperature regimes, with and without copper ion influence. The control channel ( 1 ) is always at $10{ }^{\circ} \mathrm{C}$, the experimental channels (2,3 and 4$)$ have temperature regimes which range from $10^{\circ}$ to maximum $18^{\circ} \mathrm{C}$. Standard errors are represented by the error bars attached to each column. Pale grey no copper, dark grey copper influence. Note $* * *<0.001, * *<0.003, *<0.05$

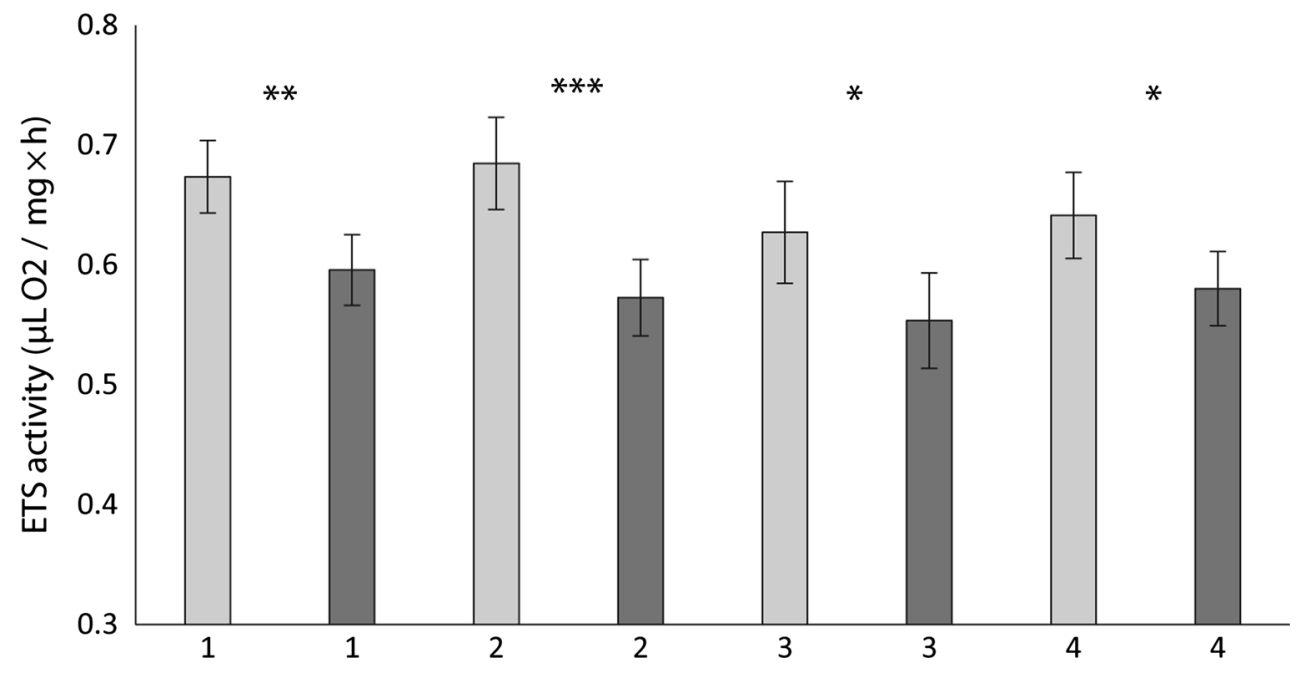

copper $(\mathrm{F} 1,121=9.558 ; \mathrm{F} 1,118=14.435 ; \mathrm{F} 1,108=$ $4.845 ; \mathrm{F} 1,102=4.939$, respectively). In all channels copper reduced the ETS activity (Fig. 2).

Temperature did not affect the ETS activity in channel 2 (F $2,118=1.75)$ significantly $(\mathrm{p}=0.178)$, but did so significantly $(\mathrm{p}=0.008 ; \mathrm{p}<0.001$, respectively $)$ in channels 3 and 4 (F 2,108=5.017; F 2,102 = 9.903, respectively) increasing the ETS activity (Fig. $3 \mathrm{a}-\mathrm{c}$ ).

\section{Discussion}

It is known that heavy metals affect the metabolic activity of organisms, their behavior and their distribution in the ecosystems and that temperature is a very important factor influencing this as well (Lemus and Chung 1999). Temperature has often been quoted to have an effect on the toxicity of pesticides and other pollutants (Fent 2007) and it has been shown that increasing temperatures increase the toxicity of copper (Holmstrup et al. 2010). We therefore assumed that higher water temperatures would significantly change the susceptibility of the tested organisms to copper.

In our experiments the feeding activity was not significantly changed by the sub-lethal copper ion concentration or higher water temperatures; however a trend towards higher feeding activity at higher water temperatures could be seen. The ETS activity of $G$. fossarum increased significantly at elevated temperatures and the presence of copper ions significantly lowered the ETS activity. Our findings demonstrate the benefit of using two different approaches when examining environmental changes on an organism.

\section{Feeding activity}

The chosen tree species can affect the feeding activity considerably and most feeding tests described in literature are conducted with Alnus glutinosa leaves (e.g. Cold and Forbes 2004; Felten et al. 2008; Bundschuh et al. 2009), these apparently being the preferred leaf species of $G$. fossarum and other detritivores (Haeckel et al. 1973; Naylor et al. 1990; Bloor 2009). We chose F. sylvatica as the food source because the springs from which the gammarids for this study were collected are surrounded by beech trees and we aimed to provide the gammarids with their natural food source. The feeding activities measured in this study are similar, albeit a bit lower, than those recorded by Maltby et al. (2002) with G. pulex. The feeding activity of our control group was however higher than the one recorded by Felten et al. (2008). In both cited studies alder leaves were used. The results of our study suggest that well-conditioned beech leaves are also a palatable food source for gammarids.

Feeding tests conducted with $G$. pulex at different temperatures showed that the consumption rose with temperature (Nilsson 1974). In an in situ study G. pulex had a lower feeding activity in April compared to August (Bloor and Banks 2006). The authors suggest that this was owing to temperature stress: in April it was too cold and hence the organisms ate less. The gammarids used in our experiments were all collected in winter between November and March and so we do not expect any seasonal effects. In our study the higher water temperatures had nearly significant effects on the feeding activity, both in the copper-free and copperexposed groups. Significance should be reached by longer test periods. In tests lasting 26 days we were able to show that increasing water temperatures increased feeding activity of $G$. fossarum significantly (Schmidlin et al. subm.). Coulaud et al. (2011) also found an increase of the feeding activity at elevated water temperatures for $G$. fossarum. The same has been shown for G. pulex by Maltby et al. (2002). A distinctly higher feeding activity of the gammarids not exposed to copper in the condition 

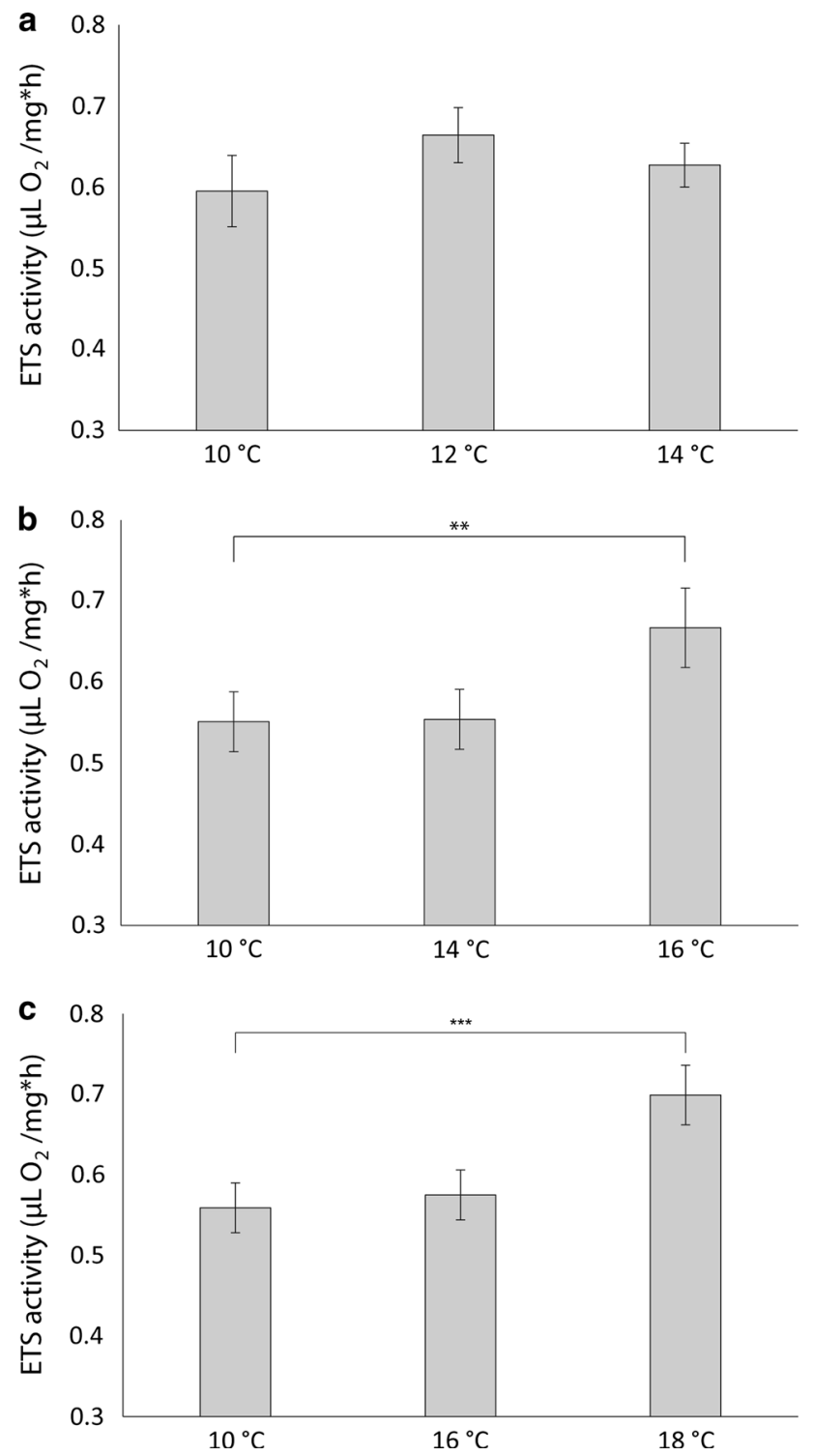

Fig. 3 a-c Mean ETS activities of G. fossarum for the channels 2 (a), 3 (b) and 4 (c) with their different temperature regimes, regardless of the copper ion influence. Standard errors are represented by the error bars attached to each column. Note $* * *<0.001, * *<0.003, *<0.05$

10-12-14 ${ }^{\circ} \mathrm{C}$ was observed. This temperature range is actually optimal for $G$. fossarum, as it has been shown that the ideal temperature for optimal reproduction lies at $12{ }^{\circ} \mathrm{C}$ (Pöckl and Humpesh 1990).

In the control condition and condition $10-12-14{ }^{\circ} \mathrm{C}$ there was a slight trend towards lower feeding activity of the gammarids exposed to copper ions compared to the gammarids not exposed to copper ions. Previously a decreasing feeding rate of G. pulex when exposed to copper was measured (Taylor et al. 1993). The concentrations they used were between 0.01 and $0.150 \mathrm{mg} / \mathrm{L} \mathrm{Cu}^{2+}$ and the highest one being nearly identical to the one used here. Their findings support our observation. It has been shown previously that the feeding rate of G. pulex decreased with increased cadmium ion concentrations (Felten et al. 2008; Alonso et al. 2009). Brief exposure of G. pulex to high concentrations of Lindane has been shown to have the largest effect on the feeding rate of $G$. pulex during the first $24 \mathrm{~h}$ after exposure (Malbouisson et al. 1995). The feeding activities in our study may have been lower after the first few hours of exposure and then, owing to adaption, rise slightly to a constant level. We cannot be sure of this because we determined a feeding activity for the entire duration of the experiment.

We assumed that higher temperatures would enhance the negative effects of copper ion exposure and so reduce the feeding activity. Furthermore we assumed that elevated temperatures would cause higher metabolic activity and so an increase in feeding activity would take place. Higher temperatures did not cause a clear increase in the feeding activity of $G$. fossarum in this study and the copper ions did not significantly reduce the feeding activity. A reason for the copper ions not having a significant effect on the feeding activity is most likely because a sub-lethal copper ion concentration was chosen for these tests. A further reason may be that partial adsorption of the copper ions to the leaf discs (Tattersfield 1993) reduced the copper ion concentration in the water and this in turn might explain why the feeding activity at the higher temperatures was not significantly higher. The average water temperatures of the four channels $\left(10,12,13.3\right.$ and $\left.14.7^{\circ} \mathrm{C}\right)$ are not as different from each other as the temperature regimes might suggest, but the temperature jumps are far more important, since these doubtlessly affected the gammarids. The temperature jumps in channels 3 and 4 are extreme. We speculate that the gammarids had to first become accustomed to the much higher temperature (i.e. from 10 to $14{ }^{\circ} \mathrm{C}$ and 10 to $16^{\circ} \mathrm{C}$ ) before they resumed feeding which resulted in an overall similar feeding activity to the control $10-10-10{ }^{\circ} \mathrm{C}$. The feeding activity of $G$. fossarum was highest in the channel 2, where the jumps of $2{ }^{\circ} \mathrm{C}$ from 10 to $12{ }^{\circ} \mathrm{C}$ and then to $14{ }^{\circ} \mathrm{C}$ effectively made the conditions for G. fossarum more optimal.

\section{ETS activity}

Our ETS results show that a change on the cellular level of the organisms was caused both by increased temperature and copper ion exposure. In two previously published studies the ETS activities for $G$. fossarum ranged from 0.4 to $0.48 \mu \mathrm{L} \mathrm{O} \mathrm{O}_{2} / \mathrm{mg} \times \mathrm{h}$ and from 0.39 to $0.45 \mu \mathrm{L} \mathrm{O}_{2} /$ $\mathrm{mg} \times \mathrm{h}$ (Lukancic et al. 2010; Simcic 2005). During fasting the ETS activity of $G$. fossarum has also been found to be in a similar range $\left(0.36-0.58 \mu \mathrm{L} \mathrm{O} \mathrm{O}_{2} / \mathrm{mg} \times \mathrm{h}\right)$ (Mezek et al. 2010). These activities are just slightly lower than the ones recorded in our study.

With rising water temperatures we measured a significant increase of the ETS activity of G. fossarum within the 
copper-free and copper-exposed groups in channels three and four. An increase in ETS activity with increasing water temperatures has also been observed e.g. for daphnid species and hybrids: both juveniles and adults displayed a higher ETS activity at higher temperatures (Simcic and Brancelj 1997; Simcic and Brancelj 2004). The absolute ETS activities of channels two, three and four are lower than those of the control channel at the same point in time. This can be explained by two competing factors: with higher temperatures the metabolism of the organisms is more efficient, on the other hand the oxygen concentration is lower the higher the temperature becomes.

G. fossarum exposed to copper showed significant decreases in ETS activity compared to those in pure spring water. It has been shown that a copper ion concentration of $10 \mu \mathrm{g} \mathrm{Cu}^{2+} / \mathrm{L}$ caused a small but significant increase in the ETS activity of mixed zooplankton while the lower concentration of $5 \mu \mathrm{g} \mathrm{Cu}^{2+} / \mathrm{L}$ had no significant effect (Bamsted 1980). On the other hand it has been found that Atrazine and Imidacloprid reduced the ETS activity of $G$. fossarum (Lukancic et al. 2010). Bamsted's observation of an increase in ETS activity emphasizes that different taxa react differently to metal pollution. It has also been demonstrated that cadmium and chromium affected the ETS activity of Daphnia magna differently: cadmium did not affect cellular respiration after $48 \mathrm{~h}$ of exposure; chromium however caused an increase after $48 \mathrm{~h}$ and a decrease after $96 \mathrm{~h}$ of exposure in the ETS activity (De Coen and Janssen 2003). This is similar to the ETS activities we measured in the copper-exposed gammarids at the temperature regimes 10 to $14{ }^{\circ} \mathrm{C}$ and 10 to $16{ }^{\circ} \mathrm{C}$, where the ETS activity did not increase continuously but fluctuated. Many enzymes are organometallic compounds (Meyer 2001) and hence one would expect heavy metals to have some effect on the enzyme activity which would reflect in the ETS activity.

\section{Implications for springs}

The results of this study show that the exposure to $\mathrm{Cu}^{2+}$ ions coupled with a higher temperature has the potential to be stressful to G. fossarum. A temperature elevation on its own, however, is unlikely to be very problematic for eurythermal species as can be seen from our results. In a study by Pöckl et al. (2003) it was concluded that a temperature rise in rivers with a current mean temperature of 7 to $10^{\circ} \mathrm{C}$ would not affect $G$. fossarum and $G$. roeslii greatly, but a warming of colder rivers would have a positive effect for the gammarids and that a warming of already warm flowing waters would be negative. His study underpins our assumption that $G$. fossarum is fairly tolerant towards slightly elevated temperatures, with the clear understanding that these do however influence their life history, especially when coupled with pesticides and other pollutants, and that larger temperature elevations of more than $4{ }^{\circ} \mathrm{C}$ are problematic. However, G. fossarum has a narrower distribution than $G$. pulex because it is more sensitive to environmental variables and is also often more sensitive towards pollutants (Alonso et al. 2010). G. fossarum probably also does not occur in warmer waters because G. pulex is the stronger of the two competitors, being more robust towards higher water temperatures up to $27{ }^{\circ} \mathrm{C}$ (Foucreau et al. 2014; Sutcliffe et al. 1981) and so $G$. fossarum is forced into colder waters.

Assuming Global Change raises temperatures further this might nevertheless bring the gammarids into difficulties, because raised metabolisms and hence higher feeding activity could cause food to become a limiting factor, because allochthonous in-put of leaf litter is finite.

Although springs are known for their clean water, pollution of these unprotected habitats in Switzerland (Zollhöfer 1997) can occur. Our study demonstrates the importance of clean spring water for organisms, especially when an increase in water temperatures cannot be prevented. The findings emphasize the need for springs and headwaters and their species to be protected from pesticide inputs and other forms of pollution and to be monitored regularly. We worked with G. fossarum in this study as an abundant representative of spring species and have been able to show that a gradual temperature elevation will probably not pose a problem for G. fossarum and other eurythermal species. G. fossarum nevertheless reacted when exposed to copper ion and elevated temperatures. It can be deduced that exposure to a pollutant will be tolerated even worse by cold-stenothermal organisms and they will most probably react much more sensitively to elevated temperatures. It has been shown that the respiratory ETS activity in cold-stenothermal and eurythermal chironomid larvae from high mountain lakes increased with rising temperatures for two chironomid genera (Simcic et al. 2005). Different responses to temperature changes were observed between cold-stenothermal and eurythermal genera, especially at high temperatures. The findings of Simcic et al. (2005) are in accordance with the assumption that cold-stenothermal spring species would react even more sensitively to temperature changes. While the ability of survival of many species may decrease, a few species might find more ecological niches to live in and hence their populations might increase. A consequence of environmental pollution and changes will, however, presumably be an overall loss of biodiversity in springs.

\section{Conclusions}

Higher water temperatures increase the metabolic activity of $G$. fossarum and copper ions have a tendency to decrease 
the feeding activity and significantly decrease ETS activity of the tested organisms. G. fossarum can cope with a slight elevation in temperature; copper however impairs its general fitness. The ETS assay has proved to be more sensitive in detecting the effects of sub-lethal copper ion concentrations on the metabolic activity of G. fossarum than the feeding tests. Therefore we propose the usage of the ETS assay in addition to the well-established feeding tests for more detailed results. Further experiments will be conducted with a cold-stenothermal species in order to test its responses to a temperature increase and exposure to copper.

Acknowledgments The Janggen-Pöhn-Stiftung supported the PhD project by partially financing the main author. T. Simcic kindly introduced us to the ETS method. C. Clarke proof-read the manuscript. Thanks are owing to five anonymous reviewers, who made valuable comments on the manuscript. Thanks are also owing to further numerous people, especially to the first author's family for valuable technical support and discussions.

Conflict of interest The authors declare that they have no conflict of interest.

\section{References}

Alonso A, De Lange HJ, Peeters ETHM (2009) Development of a feeding behavioural bioassay using the freshwater amphipod Gammarus pulex and the multispecies freshwater biomonitor. Chemosphere 75:341-346

Alonso A, De Lange HJ, Peeters ETHM (2010) Contrasting sensitivities to toxicants of the freshwater amphipods Gammarus pulex and G. fossarum. Ecotoxicol 19:133-140

Bamsted U (1980) ETS activity as an estimator of respiratory rate of zooplankton populations. The significance of variations in environmental factors. J Exp Mar Biol Ecol 42:267-283

Bat L, Akbulut M, Culha M, Gündogdu A, Satilmis HH (2000) Effect of temperature on the toxicity of zinc, copper and lead to the freshwater amphipod Gammarus pulex pulex (L., 1758). Turk J Zool 24:409-415

Bloor M (2009) Aquatic pollution. Case study of landfill leachate toxicity and remediation. VDM Verlag, Germany

Bloor MC (2010) Animal standardisation for mixed species ecotoxicological studies: establishing a laboratory breeding programme for Gammarus pulex and Asellus aquaticus. Zoologica baetica 21:179-190

Bloor MC, Banks CJ (2006) An evaluation of mixed species in situ and ex situ feeding assays: the altered response of Asellus aquaticus and Gammarus pulex. Environ Int 32:22-27

Brooks SJ, Mills CL (2003) The effect of copper on osmoregulation in the freshwater amphipod Gammarus pulex. Comp Biochem Physiol Part A 135:527-537

Bundschuh M, Hahn T, Gessner MO, Schulz R (2009) Antibiotics as a chemical stressor affecting an aquatic decomposer-detritivore system. Environ Toxicol Chem 28:197-203

Clesceri LS, Eaton AD, Greenberg AE (1998) Standard methods for the examination of water and wastewater, 20th edn. American Public Health Organization, Washington

Cold A, Forbes VE (2004) Consequences of a short pulse of pesticide exposure for survival and reproduction of Gammarus pulex. Aquat Toxicol 67:287-299
Coulaud R, Geffard O, Xuereb B, Lacaze E, Quéau H, Garric J, Charles S, Chaumot A (2011) In situ feeding assay with Gammarus fosssarum (Crustacea): modelling the influence of confounding factors to improve water quality biomonitoring. Water Res 45:6417-6429

Danks HV, Williams DD (1991) Arthropods of springs, with particular reference to Canada: synthesis and needs for research. Mem Ent Soc Can 155:203-217

De Coen WM, Janssen CR (2003) The missing biomarker link: relationships between effects on the cellular energy allocation biomarker of the toxicant-stressed Daphnia magna and corresponding population characteristics. Environ Toxicol Chem 22:1632-1641

De Martins MG, Barcarolli IF, De Menezes EJ, Giacimin MM, Wood CM, Bianchini A (2011) Acute toxicity, accumulation and tissue distribution of copper in the blue crab Callinectes sapidus acclimated to different salinities: in vivo and in vitro studies. Aquat Toxicol 101:88-99

De Oliveira-Filho EC, Lopes RM, Paumgartten FJR (2004) Comparative study on the susceptibility of freshwater species to copperbased pesticides. Chemosphere 56:369-374

Debelius B, Forja JM, DelValls A, Lubian L (2009) Toxicity and bioaccumulation of copper and lead in five marine microalgae. Ecotoxicol Environ Saf 72:1503-1513

Dedourge-Geffard O, Palais F, Biagianti-Risbourg S, Geffard O, Geffard A (2009) Effects of metals on feeding rate and digestive enzymes in Gammarus fossarum: an in situ experiment. Chemosphere 77:1569-1576

Effler SW, Litten S, Field SD, Tong-Ngork T, Hale F, Meyer M, Quirk M (1980) Whole lake responses to low level copper sulphate treatment. Water Res 14:1489-1499

Felten V, Charmantier G, Mons R, Geffard A, Rousselle P, Coquery M, Garric J, Geffard O (2008) Physiological and behavioural responses of Gammarus pulex (Crustacea: Amphipoda) exposed to cadmium. Aquat Toxicol 86:413-425

Fent K (2007) Ökotoxikologie, 3rd edn. Thieme Verl, Stuttgart/New York

Ferrington LC (1995) Biodiversity of aquatic insects and other invertebrates in springs: introduction. J Kans Entomol Soc. $68: 1-3$

Fischer J, Fischer F, Schnabel S, Bohle HW (1998) Spring fauna of the Hessian Mittelgebirge: population structure, adaptative strategies, and relations to habitats of the macroinvertebrates, as exemplified by springs in the Rhenisch metamorphic shieldand in the East-Hessian sandstone plate. In: Botosaneanu L (ed) Studies in crenobiology. The biology of springs and springbrooks. Backhuys Publishers, Leiden, pp 182-199

Foucreau N, Cottin D, Piscart C, Hervant F (2014) Physiological and metabolic responses to rising temperature in Gammarus pulex (Crustacea) populations living under continental or Mediterranean climates. Comp Biochem Physiol Part A 168:69-75

Geffard A, Sartelet H, Garric J, Biagianti-Risbourg S, Delahaut L, Geffard O (2010) Subcellular compartmentalization of cadmium, nickel, and lead in Gammarus fossarum: comparison of methods. Chemosphere 78:822-829

Guida M, Inglese M, Meric S (2008) A multi-battery toxicity investigation on fungicides. Desalination 226:262-270

Güven K, Özbay C, Ünlü E, Satar A (1999) Acute lethal toxicity and accumulation of copper in Gammarus pulex (L.) (Amphipoda). Turk J Biol 23:513-521

Haeckel JW, Meijering MPD, Rusetzki H (1973) Gammarus fossarum Koch als Fallaubzersetzer in Waldbächen. Freshw Biol 3:241-249

Heino J, Virkkala R, Toivonen H (2009) Climate change and freshwater biodiversity: detected patterns, future trends and adaptations in northern regions. Biol Rev 84:39-54 
Holmstrup M, Bindesbøl A-M, Oostingh GJ, Duschl A, Scheil V, Köhler H-R, Loureiro S, Soares AMVM, Ferreira ALG, Kienle C, Gerhardt A, Laskowski R, Kramarz PE, Bayley M, Svendsen C, Spurgeon DJ (2010) Interactions between effects of environmental chemicals and natural stressors: a review. Sci Total Environ 408:3746-3762

IPCC (2007) Climate change, 2007. Synthesis report. In: Pachauri RK, Reisinger A (eds) Contribution of working groups 1, 2 and 3 to the fourth assessment report of the intergovernmental panel on climate change. IPCC, Geneva

Janetzky W (1994) Distribution of the genus Gammarus (Amphipoda: Gammaridae) in the River Hunte and its tributaries (Lower Saxony, northern Germany). Hydrobiologia 294:23-34

Jonsson M, Malmquist B (2000) Ecosystem process rate increases with animal species richness: evidence from leaf-eating, aquatic insects. Oikos 89:519-523

Kenner RA, Ahmed SI (1975) Measurements of electron transport activities in marine phytoplancton. Mar Biol 33:119-127

Komarek M, Cadkova E, Chrastny V, Bordas F, Bollinger JC (2010) Contamination of vineyard soils with fungicides: a review of environmental and toxicological aspects. Environ Int 36:138-151

Ladewig V, Jungmann D, Köhler H-R, Schirling M, Triebskorn R, Nagel R (2006) Population structure and dynamics of Gammarus fossarum (Amphipoda) upstream and downstream from effluents of sewage treatment plants. Arch Environ Contam Toxicol 50:370-383

Lebrun JD, Perret M, Geffard A, Gourlay-Francé C (2012) Modelling copper bioaccumulation in Gammarus pulex and alterations of digestive metabolism. Ecotoxicology 21:20022-22030

Lemus MJ, Chung KS (1999) Effect of temperature on copper toxicity, accumulation and purification in tropical fish Juveniles Petenia Kraussii (Pisces: Cichlidae). Caribb J Sci 35:64-69

Lindegaard C, Brodersen KB, Wiberg-Larsen P, Skriver J (1998) Multivariate analyses of macrofaunal communities in Danish springs and springbrooks. In: Botosaneanu L (ed) Studies in Crenobiology. The Biology of Springs and Springbrooks 201-219. Backhuys Publishers, Leiden

Litchfield JT Jr, Wilcoxon F (1948) A simplified method of evaluating dose-effect experiments. Stamford Research Laboratories, American Cyanamid Company, Stamford

Lukancic S, Zibrat U, Mezek T, Jerebic A, Simcic T, Brancelj A (2009) Effects of exposing two non-target crustacean species, Asellus aquaticus L., and Gammarus fossarum Koch, to Atrazine and Imidacloprid. Bull Environ Contam Toxicol 84:85-90

Lukancic S, Zibrat U, Mezek T, Jerebic A, Simcic T, Brancelj A (2010) A new method for early assessment of effects of exposing two non-target crustacean species, Asellus aquaticus and Gammarus fossarum, to pesticides, a laboratory study. Toxicol Ind Health 26:217-228

Malbouisson JFC, Young TWK, Bark AW (1995) Use of feeding rate and repairing of precopulatory Gammarus pulex to assess toxicity of Gamma-Hexachlorocyclohexane (Lindane). Chemosphere 30:1573-1583

Maltby L, Clayton SA, Wood RM, McLoughlin N (2002) Evaluation of the Gammarus pulex in situ feeding assay as a biomonitor of water quality: robustness, responsiveness, and relevance. Environ Toxicol Chem 21:361-368

Meyer F (2001) Wie die Natur Chemie betreibt. Universität Heidelberg Ruperto Carola 3, Heidelberg

Mezek T, Simcic T, Arts MT, Brancelj A (2010) Effect of fasting on hypogean (Niphargus stygius) and epigean (Gammarus fossarum) amphipods: a laboratory study. Aquat Ecol 44:397-408

Moog O (1995) Fauna Aquatica Austriaca. Wasserwirtschaftskataster. Bundesministerium für Land- und Forstwirtschaft, Wien

Naylor C, Maltby L, Calow P (1990) Scope for growth in Gammarus pulex, a freshwater benthic detritivore. Hydrobiologia 188(189): $517-523$
Newmann MC (2010) Fundamentals of ecotoxicology, 3rd edn. CRC Press Taylor and Francis Group, Boca Raton

Nilsson LM (1974) Energy Budget of a laboratory population of Gammarus pulex (Amphipoda). Oikos 25:35-42

Packard TT (1971) The measurement of respiratory electron transport system activity in marine phytoplankton. J Mar Res 29:235-244

Pestana JLT, Re A, Nogueira AJA, Soares AMVM (2007) Effects of cadmium and zinc on the feeding behaviour of two freshwater crustaceans: Atyaephyra desmarestii (Decapoda) and Echinogammarus meridionalis (Amphipoda). Chemosphere 68: $1556-1562$

Pöckl M, Humpesh UH (1990) Intra- and inter-specific variations in egg survival and brood development time for Austrian populations of Gammarus fossarum and $G$. roeseli (Crustacea: Amphipoda). Freshw Biol 23:441-455

Pöckl M, Webb BW, Sutcliffe DW (2003) Life history and reproductive capacity of Gammarus fossarum and G. roeseli (Crustacea: Amphipoda) under naturally fluctuating water temperatures: a simulation study. Freshw Biol 48:53-66

Reichmuth JM, Weis P, Weis JS (2010) Bioaccumulation and depuration of metals in blue crabs (Callinectes sapidus Rathbun) from contaminated and clean estuary. Environ Pollut 158: 361-368

Rinderhagen M, Ritterhof J, Zauke G (2000) Crustaceans as bioindicators. In: Gerhardt A (ed) Biomonitoring of polluted water-reviews on actual topics, vol 9., Environmental Research ForumTrans Tech Publications - Scitech Publications, UetikonZuerich, pp 161-194

Ruyters S, Salaets P, Oorts K, Smolders E (2013) Copper toxicity in soils under established vineyards in Europe: a survey. Sci Total Environ 443:470-477

Schönborn W, Risse-Buhl U (2013) Lehrbuch der Limnologie. 2. Vollständig überarbeitet Auflage. Schweizerbart, Stuttgart, $p 471$

Simcic T (2005) Respiratory electron transport system (ETS) activity and respiration rate in cold-stenothermal and eurythermal chironomid larvae from high-mountain lakes. Archiv für Hydrobiologie 162:399-415

Simcic T, Brancelj A (1997) Electron transport system (ETS) activity and respiration rate in five Daphnia species at different temperatures. Hydrobiologia 360:117-125

Simcic T, Brancelj A (2004) Respiratory electron transport system (ETS) activity as an estimator of the thermal tolerance of two Daphnia hybrids. J Plankton Res 26:525-534

Simcic T, Brancelj A (2006) Effects of pH on electron transport system (ETS) activityand oxygen consumption in Gammarus fossarum, Asellus aquaticus and Niphargus sphagnicolus. Freshw Biol 51:686-694

Simcic T, Lukancic S, Brancelj A (2005) Comparative study of electron transport system activity and oxygen consumption of amphipods from caves and surface habitats. Freshw Biol 50:494-501

Sridhar KR, Krauss G, Bärlocher F, Raviraja NS, Wennrich R, Baumbach R, Krauss G-J (2001) Decomposition of alder leaves in two heavy metal-polluted streams in central Germany. Aquat Microb Ecol 26:73-80

Sutcliffe DW, Carrick TR, Willoughby LG (1981) Effects of diet, body size, age and temperature on growth rates in the amphipod Gammarus pulex. Freshw Biol 11:183-214

Tattersfield LJ (1993) Effects of copper on the energy budget of a stream detritivore: validation and ecological relevance. Dissertation. University of Sheffield

Taylor HH, Anstiss JM (1999) Copper and haemocyanin dynamics in aquatic invertebrates. Mar Freshw Res 50(8):907-931

Taylor EJ, Jones DPW, Maund SJ, Pascoe D (1993) A new method for measuring the feeding activity of Gammarus Pulex (L.). Chemosphere 26:1375-1381 
Taylor EJ, Underhill KM, Blockwell SJ, Pascoe D (1998) Haem biosynthesis in the freshwater macroinvertebrate Gammarus pulex (L.): effects of copper and Lindane. Water Res 32:2202-2204

Toth GL (1999) Aktivität des Elektronentransportsystems. In: von Tümpling W, Friedrich G (eds) Biologische Gewässeruntersuchung. Methoden der Biologischen Wasseruntersuchung 2. Gustav Fischer Verl., Jena, Stuttgart, Lübeck, Ulm, pp 465-473

Vittoz P, Cherix D, Gonseth Y, Lubini V, Maggini R, Zbinden N, Zumbach S (2013) Climate change impacts on biodiversity in Switzerland: a review. J Nat Conserv 21:154-162

Von Fumetti S, Nagel P (2012) Discharge variability and its effect on faunistic assemblages in springs. Freshw Sci 31:647-656

Wagner R (1990) Influence of temperature, photoperiod and nutrition on growth and consumption of Chaetopteryx Villosa (Trichoptera). Holarct. Ecol 13(3):247-254
Webb DW, Wetzel MJ, Reed PC, Philippe LR, Young TC (1998) The macroinvertebrate biodiversity, water quality, and hydrogeology of ten karst springs in the Salem Plateau of Illinois. In: Botosaneanu L (ed) Studies in crenobiology: the biology of springs and springbrooks. Backhuys Publishers, Leiden, pp 39-48

Woodward G, Friberg N, Hildrew AG (2009) The need for scientific rigour in biomonitoring and conservation of fresh waters Freshwater ecosystems: biodiversity, management and conservation. Nova, Hauppage

Woodward G, Perkins DM, Brown LE (2010) Climate change and freshwater ecosystems; impacts across multiple levels of organization. Philos Trans R Soc B 365:2093-2106

Zollhöfer JM (1997) Quellen - die unbekannten Biotope im Schweizer Jura und Mittelland. Erfassen -Bewerten - Schützen. Bristol Stiftung, Zürich 